\title{
Ocular trauma score in transferred fireworks-related ocular injuries: a case series
}

\author{
Havai fişek taşımasında olan göz yaralanmalarında oküler travma skoru: \\ Olgu serisi
}

\author{
Yong LIU, ${ }^{1}$ Yi-Fei HUANG, ${ }^{2}$ Jing-Jing JIANG, ${ }^{2}$ Ji-Feng YU, ${ }^{2}$ \\ Yu-Bo GONG, ${ }^{2}$ Xi-Bin ZHOU, ${ }^{2}$ Gai-Ping DU, ${ }^{2}$ Qian-Qian $X^{2}$
}

\section{BACKGROUND}

Our aim was to review the characteristics of transferred fireworks-related ocular damage and to evaluate the prognostic value of the ocular trauma score (OTS) for these injuries.

\section{METHODS}

This study included 22 transferred patients (19 male, 3 female; mean age $22.6 \pm 14.9$ years) (25 eyes). The data were retrospectively reviewed, including the characteristics of the geography, types of fireworks, status of injuries, therapeutic procedures, and the best-corrected visual acuity (BCVA). All the injured eyes were classified using the OTS at the time of the initial examination.

\section{RESULTS}

Twenty eyes $(80 \%)$ were in OTS category 1 , three eyes $(12 \%)$ were in OTS category 2 , and two eyes $(8 \%)$ were in OTS category 3. All cases received surgical therapy. Six eyes $(24 \%)$ were enucleated, four $(16 \%)$ of which achieved an improvement in their final BCVA. There was a statistically significant improvement in final BCVA between OTS category 1 and the other two OTS categories $(\mathrm{p}=0.016)$.

\section{CONCLUSION}

The aforementioned transferred fireworks-related ocular injury cases occurred mainly in young adults, men and active participants, all of which incurred serious vision loss and blindness. The OTS is quite effective for classifying the status and estimating the prognosis of transferred fireworks-related ocular injuries.

Key Words: Fireworks; ocular injury; transfer; scores; prognosis; ocular trauma score (OTS).

\section{$\boldsymbol{A M A C}$}

Bu çalışmada amacımız, taşınan havai fişekle ilgili oküler hasar özelliklerini gözden geçirmek ve bu yaralanmalar için oküler travma skorunun (OTS) prognostik değerini araştırmaktır.

\section{GEREÇ VE YÖNTEM}

Bu çalışmaya, 22 taşınan hasta (19 erkek, 3 kadın; ortala-

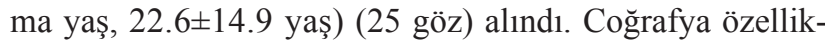
leri, havai fişek tipleri, yaralanma durumu, terapötik prosedürler ve en iyi düzeltmiş görme keskinliği (BCVA) ile ilgili karakteristikleri içeren veriler geriye dönük değerlendirildi. Yaralanan bütün gözler, ilk inceleme sırasında OTS kullanılarak sınıflandırıldı.

\section{BULGULAR}

Yirmi göz (\%80) OTS kategori 1, üç göz (\%12) OTS kategori 2 ve iki göz (\%8) OTS kategori 3 olarak değerlendirildi. Bütün olgular cerrahi tedavi aldı. Altı göz (\%24) enükle idi, bunların dördünde (\%16) son BCVA'larında bir düzelme oldu. OTS kategori 1 ile diğer iki OTS kategorisi arasında son BCVA'da istatistiksel olarak anlamlı bir düzelme oldu $(\mathrm{p}=0,016)$.

\section{SONUÇ}

Taşınan havai fişek ile ilişkili oküler yaralanma olguları, esas olarak genç erişkinler, erkekler ile aktif katılımcılarda oluşmuş ve hepsi de ciddi görme kaybı ve körlüğe maruz kalmıştır. OTS, taşınan havai fişek ile ilişkili oküler yaralanmaların durumunun sinıflandırılmasında ve prognozunun tahmin edilmesinde oldukça etkindir.

Anahtar Sözcükler: Havai fişek; oküler yaralanma; taşınma; skorlar; prognoz; oküler travma skoru (OTS). 
Fireworks are used during many celebrations internationally; however, they are dangerous if people do not give due attention to the necessary safety measures. Injuries from fireworks remain a problem in several countries. ${ }^{[1-3]}$ For example, fireworks were involved in an estimated 8,800 injuries in the United States (U.S.) hospital emergency departments in 2009 (95\% confidence interval of 6,800 to 10,800$).^{[1]}$ The U.S. Consumer Product Safety Commission (CPSC; Bethesda, MD, USA) staff estimated that there were 7,000 fireworks-related injuries during 2008. ${ }^{[1]}$ The CPSC also estimated that $92 \%$ of the victims of fireworks-related injuries were treated in the emergency department and then released. In 2009, approximately $2 \%$ of the victims were treated and transferred to another hospital, and slightly more than $5 \%$ were admitted to the hospital. ${ }^{[1]}$ Ocular damage/harm was one of the most common fireworks-related injuries. ${ }^{[2-4]}$ Setting off fireworks is also a tradition during the Spring Festival in China, which symbolizes the coming of the Chinese lunar new year, and as a result, many ocular injuries are sustained during this period. ${ }^{[5]}$ As a tertiary referral hospital and the largest military hospital in China, the Chinese PLA General Hospital treated mainly transferred, fireworks-related ocular injury patients. To review the characteristics of these transferred ocular injuries and the results of treatments, this retrospective study concentrated on 22 patients ( 25 eyes) who were transferred to the Chinese PLA General Hospital during the period of the previously mentioned Spring Festivals from 2006 to 2010. This study was approved by the Ethical Board Committee of the Chinese PLA General Hospital.

Fireworks-related ocular injuries included in the study covered a wide spectrum of ocular trauma in terms of anatomical involvement, such as superficial and deep injuries (i.e., ranging from the eyelids to the optic nerve); the type of injury, for instance, penetration, contusion, rupture, and intraocular foreign body (IOFB); as well as the mechanism of injury, including, but not limited to, blunt, penetrating, and/or thermal wounds. ${ }^{[6,7]}$ At the time of this study, there were no specialized scoring systems available for classifying fireworks-related ocular injuries. To obtain a quantifying analysis on the status of these transferred ocular injuries, the study classified these injuries by means of the ocular trauma score (OTS). The OTS was published in 2002 and can provide good estimations of the prognosis of ocular trauma. This system was mainly used to classify the mechanical injuries of the eye. It describes the anatomic and functional status of the eye following trauma. Its purpose is to standardize the diagnosis, and it serves to identify characteristics associated with greater severity of the initial eye condition. According to the score obtained from this scale, the injured eye can be placed into one of five categories, each of which has a distinct probability of reaching a range of visual function. ${ }^{[8,9]}$ Though many studies have focused on characteristics of fireworks-related ocular injuries, the quantitative analysis on the type of trauma was insufficient. Therefore, our aim was to prospectively analyze these transferred fireworksrelated ocular injuries by means of the OTS. The OTS results will help us quantitatively evaluate the characteristics of ocular fireworks injuries and to evaluate the prognostic value of OTS for these injuries.

\section{MATERIALS AND METHODS}

For this study, we performed an observational, retrospective study on patients who were transferred from community hospitals into the Ophthalmology Department of the Chinese PLA General Hospital. Medical histories were obtained via the medical records of all patients. All transferred patients with fireworks-related ocular injuries between January 2006 and March 2010 were included, and we extracted demographic information, types of fireworks used most often and which type frequently resulted in eye injury, sites and severities of the injuries, and the diagnosis and management of each, as well as the patients' condition at the time of discharge and the last follow-up examination.

All patients were examined by slit-lamp biomicroscopy, ophthalmotonometer, gonioscopy, direct and indirect ophthalmoscopy, and type B ultrasonic scan, in the event that the posterior segment status, such as retinal detachment (RD) or vitreous hemorrhage, was not well-visualized. Furthermore, computerized tomography (CT) scan was performed if needed to rule out IOFB.

For this study, we used the OTS to classify patients at their initial examination in our hospital. This classification system distinguished between closed- (CG) and open- globe (OG) trauma. The aforementioned trauma was classified as A, B, C and D when the globe was closed: A, contusion; B, lamellar laceration; $\mathrm{C}$, superficial foreign body; and D, mixed. In OG trauma, type A was labeled as rupture; type $\mathrm{B}$ as penetration; type $\mathrm{C}$ as IOFB; type $\mathrm{D}$ as perforation (2 continuity solutions for the same sharp agent); and type $\mathrm{E}$ as mixed type. Vision grade (best-corrected visual acuity [BCVA] in the injured eye and Snellen equivalents) was classified as follows: (1) $\geq 20 / 40$; (2) $20 / 50$ to $20 / 100$; (3) $19 / 100$ to $5 / 200$; (4) 200 to light perception; and (5) No light perception. The pupil was scored as positive or negative according to the presence or absence of an afferent pupillary defect, respectively. Three zones of injuries were defined by the location of the most posterior full-thickness aspect of the globe. The final score was obtained through the score of the initial BCVA, from which were subtracted the scores of the other characteristics (Table 1). With the final 
Table 1. Calculating the ocular trauma score (OTS) variables and raw points in the OTS study

\begin{tabular}{lc}
\hline Variables & Raw points \\
\hline Initial vision & \\
$\quad$ NLP & 60 \\
LP/HM & 70 \\
$1 / 200$ to $19 / 200$ & 80 \\
$20 / 200$ to $20 / 50$ & 90 \\
$20 / 40$ & 100 \\
Rupture & 23 \\
Endophthalmitis & 17 \\
Perforating injury & 14 \\
Retinal detachment & 11 \\
Afferent pupillary defect & 10 \\
\hline
\end{tabular}

HM: Hand movements; LP: Light perception; NLP: No light perception.

Table 2. Demographic information $(\mathrm{n}=22)$

\begin{tabular}{lcc}
\hline Variable & $\mathrm{n}$ & $\%$ \\
\hline Age (years) & & \\
$\quad<10$ & 4 & 18 \\
10 to 18 & 7 & 32 \\
19 to 44 & 9 & 41 \\
45 to 59 & 2 & 9 \\
$\quad>60$ & 0 & 0 \\
Sex & & \\
$\quad$ Male & 19 & 86 \\
$\quad$ Female & 3 & 14 \\
Circumstance & & \\
$\quad$ Participant & 16 & 73 \\
$\quad$ Bystander & 6 & 27 \\
Residence & & \\
$\quad$ Rural & 15 & 68 \\
$\quad$ Urban & 7 & 32 \\
\hline
\end{tabular}

score, each eye evaluated was placed within an OTS category: category 1: 0 to 44 points, category 2: 45 to 65 points, category 3: 66 to 80 points, category $4: 81$ to 91 points, and category 5: 92 to 100 points. $^{[8,9]}$

\section{Statistical Analysis}

Follow-up examination was performed 8 to 24 months after all patients were discharged from the hospital. The Statistical Package for the Social Sci- ences (SPSS) version 15.0 (SPSS, Inc., Chicago, IL, USA) was used for all statistical analyses. Significance was set at $\mathrm{p}<0.05$. Fisher's exact test was used as appropriate.

\section{RESULTS}

A total of 22 patients ( 25 eyes) with fireworks-related ocular injuries were collected. The demographic information is shown in Table 2.

Twenty-two eyes (88\%) had OG trauma: nine eyes (36\%) had type A; two eyes had type B (8\%); four eyes had type C (16\%); three eyes had type D (12\%); and four eyes had type E (16\%). Three eyes $(12 \%)$ presented with CG trauma corresponding to type A in two eyes $(8 \%)$ and type B in one eye $(4 \%)$. Nineteen eyes $(76 \%)$ presented afferent pupillary defect. All of the injured eyes corresponded with zone III. A total

Table 4. Injury patterns $(\mathrm{n}=25)$

\begin{tabular}{|c|c|c|}
\hline $\begin{array}{l}\text { Location of firework-related } \\
\text { ocular injuries }\end{array}$ & $\mathrm{n}$ & $\%$ \\
\hline \multicolumn{3}{|l|}{ Anterior segments } \\
\hline Hyphema & 19 & 76 \\
\hline Cornea/corneosclera laceration & 17 & 68 \\
\hline Iris laceration/dialysis & 15 & 60 \\
\hline Cataract & 11 & 44 \\
\hline Cyclodialysis & 6 & 24 \\
\hline Subluxation/luxation of lens & 5 & 20 \\
\hline \multicolumn{3}{|l|}{ Posterior segment } \\
\hline Vitreous hemorrhage & 23 & 92 \\
\hline Retinal detachment & 21 & 84 \\
\hline Choroidal detachment & 17 & 68 \\
\hline Extrusion of intraocular content & 15 & 60 \\
\hline Epichoroidal space hemorrhage & 11 & 44 \\
\hline Retinal impaction & 9 & 36 \\
\hline Posterior scleral rupture & 7 & 28 \\
\hline IOFB & 4 & 16 \\
\hline \multicolumn{3}{|l|}{ Appendages of the eye } \\
\hline Eyelid laceration & 20 & 80 \\
\hline Blowout fracture & 9 & 36 \\
\hline \multicolumn{3}{|l|}{ Burns } \\
\hline Eyelid & 9 & 36 \\
\hline Ocular surface & 7 & 28 \\
\hline
\end{tabular}

Table 3. The types of fireworks-related ocular injuries

\begin{tabular}{|c|c|c|c|c|}
\hline \multirow[t]{2}{*}{ Type } & \multicolumn{2}{|c|}{ Number of cases $(n=22)$} & \multicolumn{2}{|c|}{ Number of eyes $(n=25)$} \\
\hline & $\mathrm{n}$ & $\%$ & $\mathrm{n}$ & $\%$ \\
\hline Aerial firework shells & 9 & 41 & 10 & 40 \\
\hline Firecrackers & 6 & 27 & 6 & 28 \\
\hline Bottle rockets & 3 & 14 & 5 & 20 \\
\hline Homemade fireworks & 2 & 9 & 2 & 8 \\
\hline Gravel buried with fireworks & 1 & 5 & 1 & 4 \\
\hline Unknown & 1 & 5 & 1 & 4 \\
\hline
\end{tabular}


of 20 eyes $(80 \%)$ were classified as OTS category 1 , three eyes $(12 \%)$ as OTS category 2 , and two eyes $(8 \%)$ as OTS category 3.

The types of fireworks-related ocular injuries are summarized in Table 3 . The highest proportion of cases $(41 \%)$ were injured by shells of aerial fireworks. This type of firework is not closely related with the category of OTS in this study (Fisher's exact test $p>0.05$ ): eight of 20 eyes in OTS category 1 were injured by aerial shells, while two of five eyes in OTS categories 2 and 3 were injured by the same type of fireworks.

Table 4 shows the detailed injury patterns. The most common anterior segment injuries were anterior chamber hyphema (Fig. 1a, b). Others included cor- nea/corneosclera laceration (Fig. 1a), iris laceration/ dialysis (Fig. 1b, e), cyclodialysis (Fig. 1f), and cataracts and subluxation/luxation of lens (Fig. 1a, b). The most posterior segment injuries were vitreous hemorrhage (Fig. 1c). Other injuries included RD (Fig. 1d), extrusion of intraocular content, choroidal detachment (Fig. 1d), and epichoroidal space hemorrhage, etc. The injuries of appendages of the eye were common. Twenty eyes $(80 \%)$ had eyelid laceration and nine eyes $(36 \%)$ had blowout fractures. Nine eyes (36\%) suffered first- and second-degree eyelid burns according to the classification of thermal eyelid burns. ${ }^{[10]}$ Seven eyes $(28 \%)$ had ocular surface burns of grades 1 and 2 of the Roper-Hall classification system. ${ }^{[1]}$ Ten patients (45\%) suffered a combination of first- and second-degree burns of the head, face, extremities, and trunk.
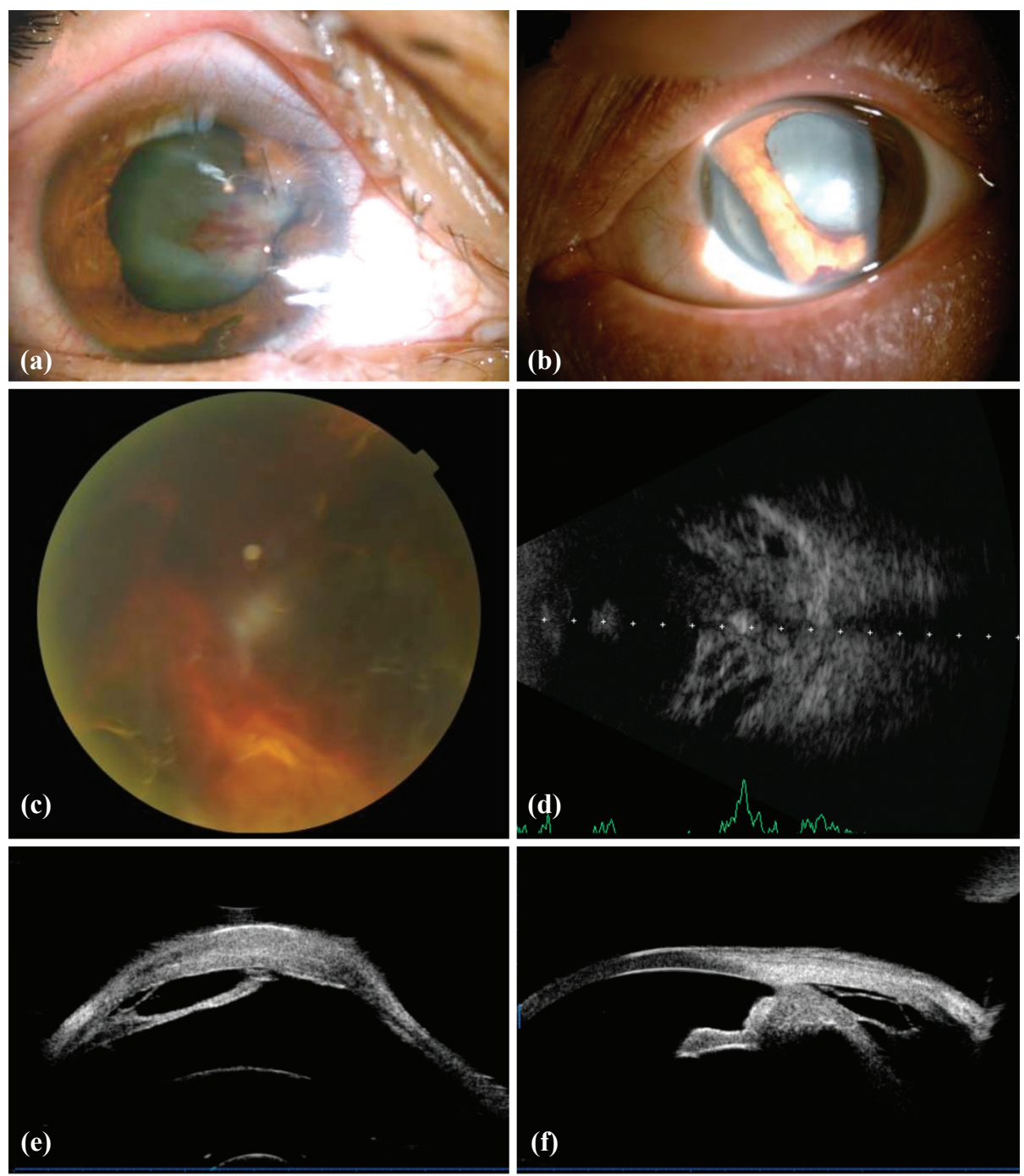

Fig. 1. Corneal open globe injury, corneal foreign bodies, and traumatic cataract are shown (a). The anterior chamber hyphema and iridodialysis (b) were shown by slit-lamp biomicroscopy examination. Vitreous hemorrhage was observed by ophthalmoscopy examination (c). Retinal and choroidal detachment was shown by B-type ultrasound scan (d). Iris laceration/dialysis (e) and cyclodialysis (f) were observed by ultrasound biomicroscopy.

(Color figures can be viewed in the online issue, which is available at www.tjtes.org). 
Table 5. BCVA at presentation and final examination

\begin{tabular}{lccccc}
\hline BCVA & \multicolumn{2}{c}{ At presentation } & & \multicolumn{2}{c}{ Final } \\
\cline { 2 - 3 } \cline { 5 - 6 } & Number of eyes $(\mathrm{n}=25)$ & & Number of eyes $(\mathrm{n}=19)$ \\
\hline $20 / 40$ & 1 & 4.0 & & 2 & 10.5 \\
$20 / 200$ to $20 / 50$ & 2 & 8.0 & & 2 & 10.5 \\
$1 / 200$ to $19 / 200$ & 1 & 4.0 & & 3 & 15.8 \\
LP to HM & 13 & 52.0 & & 11 & 57.9 \\
NLP & 8 & 32.0 & & 1 & 5.3 \\
\hline
\end{tabular}

Note: At presentation, $\mathrm{n}=25$ eyes; final, $\mathrm{n}=19$ eyes ( 6 eyes were enucleated during the follow-up).

BCVA: Best-corrected vision acuity. HM: Hand movement; LP: Light perception; NLP: No light perception.

The BCVA on presentation and at the final followup examination are summarized in Table 5. Furthermore, only one of 20 eyes in OTS category 1 achieved an improvement in final BCVA of more than one grade of vision, although three of five eyes in OTS categories 2 and 3 achieved an improvement in their final BCVA more than one grade of vision. Fisher's exact test showed a statistically significant improvement in final BCVA between the OTS category 1 and the other two OTS categories $(\mathrm{p}=0.016)$.

Table 6 shows surgical management. A total of 21 eyes $(84 \%)$ received pars plana vitrectomy and fluid/ gas exchange. Twenty eyes $(80 \%)$ received silicon oil tamponade. Eighteen eyes (72\%) received relaxing retinotomy/retinal proliferative membrane peeling for retinal incarceration and proliferative disease. Other treatments included anterior chamber washout, removal of epichoroidal space hemorrhage, and lensectomy, etc. Six eyes (24\%) were enucleated in the study: three eyes were enucleated because the scleral ruptures were up to the roots of the optic nerves and most of intraocular contents were lost during the onestage operation, and the other three eyes were enucle-

Table 6. Surgical management of ocular injuries $(n=25)$

\begin{tabular}{lcc}
\hline Management & $\mathrm{n}$ & $\%$ \\
\hline Pars plana vitrectomy/gas-fluid exchange & 21 & 84 \\
Retinal laser therapy & 21 & 84 \\
Silicon oil tamponade & 20 & 80 \\
Relaxing retinotomy/ & & \\
Retinal proliferative membrane peel & 18 & 72 \\
Anterior chamber washout & 13 & 52 \\
Removal of epichoroidal space hemorrhage & 11 & 44 \\
Pars plana lensectomy & 11 & 44 \\
Removal of silicon oil & 9 & 36 \\
Enucleation & 6 & 24 \\
Extraction of IOFB & 4 & 16 \\
Phacoemulsification and PCIOL & 3 & 12 \\
Iris repair/reconstruction & 3 & 12 \\
C3F8 tamponade & 1 & 4 \\
\hline
\end{tabular}

PCIOL: Posterior chamber intraocular lens; IOFB: Intraocular foreign body. Note: Eleven eyes had more than two surgeries including removal of silicon oil, PCIOL implantation, enucleation, etc. ated for severe eyeball atrophy during the follow-up examination. All of the enucleated eyes were classified as OTS category 1 . None of the injured eyes was diagnosed as endophthalmitis.

\section{DISCUSSION}

Many studies have reported about fireworksrelated ocular injuries during ceremonies in different countries..$^{[1-7,12,13]}$ Kuhn et al. ${ }^{[14]}$ found that $61 \%$ of serious fireworks-related cases with at least six months of follow-up therapy had a final visual acuity worse than 20/40. In order to review the results of transferred fireworks-related ocular injuries, the authors collected 22 patients ( 25 eyes) that were injured by fireworks during the Spring Festival in China. All patients were transferred to our hospital in order to obtain more professional ocular care.

Fifty percent of these cases were children and juveniles ( $<18$ years old). This consequence is consistent with the results of previous studies, which reported that $41.7 \%{ }^{[5]}$ and $69 \%{ }^{[15]}$ of fireworks-related injuries occurred in the same age group. However, for the respective group of this study, the young adults (19-44 years old) were injured more by the fireworks than other groups. The reason for this may be that young adults would more likely ignite large fireworks and firecrackers than any other age group. In this study, the main types of the fireworks-related injuries were from aerial shells and firecrackers. However, the type of firework does not closely correlate with the category of OTS in this study (Fisher's exact test $p>0.05$ ). Therefore, we conclude that the status and prognosis of the transferred ocular injuries are not connected to the type of firework involved.

Sixty-eight percent of the patients lived in rural areas. The result coincides with a previous study. ${ }^{[5]}$ One reason may be that people who live in rural areas are more apt to use lower-quality products. The gender difference of the study is in line with the results of previous studies, all of which had reported males as the high-risk group for such injuries. ${ }^{[1,5,7,12-17]}$ Sixteen $(73 \%)$ of patients were the active participants while six patients $(27 \%)$ were bystanders, which is not con- 
sistent with previous studies. ${ }^{[7,14,17]}$ We conclude that active participants are more easily injured than bystanders.

Many publications that focused on fireworks-related ocular injuries explored the clinical aspects of the problem or the impact of legislation on the injuries. $[2,4,5,13,15,17]$ Our study focused on the characteristics and prognosis of the transferred fireworks-related ocular injuries. In order to achieve a quantitative analysis, the study used the OTS to evaluate injuries. The advantages of this study are the quantitative evaluation and analysis. The disadvantage of the study is that the included cases do not represent a large sample. From the OTS results, we found that all of the transferred cases in the study incurred severe ocular injuries: $80 \%$ of the injured eyes were evaluated as OTS category 1 , while the other injured eyes were OTS categories 2 and 3. In addition, we found that the prognosis of injured eyes in OTS category 1 was poorer than that of eyes in the other two OTS categories: there was a statistically significant improvement in final BCVA between OTS category 1 and the other two OTS categories (Fisher's exact test $\mathrm{p}=0.016$ ). None of the eyes in OTS category 1 achieved an improvement in final BCVA of 20/100 or better. All injured eyes that achieved BCVA equal to or better than 20/100 were in OTS categories 2 and 3 . Furthermore, six eyes that were enucleated at the first admission and at the end of the follow-up period were in OTS category 1 .

Although the transferred cases had a combination of burn injuries that were non-mechanical injuries, the degree of the ocular burns was less than second grade according to Roper-Hall's classification system. The damage due to the ocular burns did not affect the patients' final vision or ocular integrity.

Although 20 eyes $(80 \%)$ had OG injuries, none of the injured eyes was diagnosed as endophthalmitis in this study. This result is not consistent with previous studies, which have reported that morbidity of endophthalmitis ranged from $1 \%$ to $12 \% \cdot{ }^{[5,15,18]}$ It is possible that all of the patients received timely microsurgical surgeries and anti-infection drugs; however, perhaps the sample size was too small.

Although new microsurgical techniques, such as vitrectomy, retinal laser, silicone oil, etc., are used to treat these types of injuries, the outcomes of the patients transferred with ocular injuries are not satisfactory. We need to take measures to avoid these severe fireworks-related ocular injuries. The making, selling and setting off of fireworks should be done under proper supervision to reduce and/or prevent the occurrence of severe ocular injuries.

In conclusion, we find that all transferred fireworks-related ocular injuries are severe injuries ac- cording to OTS. The injuries occur mainly in young adults, men, and active participants, all of which result in serious vision loss and blindness. The OTS is effective for evaluating the status and estimating the prognosis of transferred fireworks-related ocular injuries. The OTS results can be useful for guiding treatment and counseling patients during the initial examination in the hospital. The ocular injuries in OTS category 1 have poorer prognosis on final BCVA and on anatomical integrity of the eye than observed in the other OTS categories.

\section{REFERENCES}

1. Michael A, Greene, Yongling Tu. 2009 Fireworks Annual Report: fireworks-related deaths, emergency department treated injuries, and enforcement activities during 2009. Washington, DC: US Consumer Product Safety Commission; 2009.

2. Witsaman RJ, Comstock RD, Smith GA. Pediatric fireworksrelated injuries in the United States: 1990-2003. Pediatrics 2006; 118:296-303.

3. Knox FA, Chan WC, Jackson AJ, Foot B, Sharkey JA, McGinnity FG. A British Ophthalmological Surveillance Unit study on serious ocular injuries from fireworks in the UK. Eye (Lond) 2008;22:944-7.

4. Vassilia K, Eleni P, Dimitrios T. Firework-related childhood injuries in Greece: a national problem. Burns 2004;30:151-3.

5. Jing Y, Yi-qiao X, Yan-ning Y, Ming A, An-huai Y, Lian-hong Z. Clinical analysis of firework-related ocular injuries during Spring Festival 2009. Graefes Arch Clin Exp Ophthalmol 2010;248:333-8.

6. Mohammadi SF, Mohammadi SM, Ashrafi E, Hatef E, Rahbari H. Editorial: Chaharshanbe-Soori Fireworks and Public Health. Iranian Journal of Ophthalmology 2011;23:1-2.

7. Mansouri MR, Mohammadi SF, Hatef E, Rahbari H, Khazanehdari MS, Zandi P, et al. The Persian Wednesday Eve Festival "Charshanbe-Soori" fireworks eye injuries: a case series. Ophthalmic Epidemiol 2007;14:17-24.

8. Kuhn F, Maisiak R, Mann L, Mester V, Morris R, Witherspoon CD. The Ocular Trauma Score (OTS). Ophthalmol Clin North Am 2002;15:163-5.

9. Lima-Gómez V, Blanco-Hernández DM, Rojas-Dosal JA. Ocular trauma score at the initial evaluation of ocular trauma. Cir Cir 2010;78:209-13.

10. Malhotra R, Sheikh I, Dheansa B. The management of eyelid burns. Surv Ophthalmol 2009;54:356-71.

11. Roper-Hall MJ. Thermal and chemical burns. Trans Ophthalmol Soc U K 1965;85:631-53.

12. Tavakoli H, Khashayar P, Amoli HA, Esfandiari K, Ashegh H, Rezaii J, et al. Firework-related injuries in Tehran's Persian Wednesday Eve Festival (Chaharshanbe Soori). J Emerg Med 2011;40:340-5.

13. Sundelin K, Norrsell K. Eye injuries from fireworks in Western Sweden. Acta Ophthalmol Scand 2000;78:61-4.

14. Kuhn FC, Morris RC, Witherspoon DC, Mann L, Mester V, Módis L, et al. Serious fireworks-related eye injuries. Ophthalmic Epidemiol 2000;7:139-48.

15. Singh DV, Sharma YR, Azad RV. Visual outcome after fireworks injuries. J Trauma 2005;59:109-11.

16. Levitz LM, Miller JK, Uwe M, Drüsedau H. Ocular injuries caused by fireworks. J AAPOS 1999;3:317-8. 
17. Rashid RA, Heidary F, Hussein A, Hitam WH, Rashid RA, Ghani ZA, et al. Ocular burns and related injuries due to fireworks during the Aidil Fitri celebration on the East Coast of the Peninsular Malaysia. Burns 2011;37:170-3.
18. Mansouri M, Faghihi H, Hajizadeh F, Rasoulinejad SA, Rajabi MT, Tabatabaey A, et al. Epidemiology of open-globe injuries in Iran: analysis of 2,340 cases in 5 years (report no. 1). Retina 2009;29:1141-9. 